\title{
A General Survey of Larval Euphausiids, with a Scheme for their Identification.
}

\author{
By \\ Marie V. Lebour, D.Sc., \\ Naturalist at the Plymouth Laboratory.
}

With 1 Figure in the Text.

WHILST working at the life histories of the euphausiids occurring in the English Channel, and also having had opportunities of examining the larvæ of several other species belonging to different genera from various localities, the writer noted certain features in the larvæ which usually enabled the genus to be distinguished easily. The chief specimens were obtained from plankton collected by Mr. F. S. Russell within a radius of twelve miles from Alexandria, Egypt, whilst working for the Egyptian Fisheries Department. The larval euphausiid material from this collection is rich, and an account of it will soon be published. In the meantime the following general notes are offered, as at present little is known of the systematics of euphausiid larvæ. As several workers are occupied with this group, so important from the point of view of the Fisheries, it seemed advisable to bring all that is known together. In so doing it has been found possible to form a working scheme, from which, being given a series of larvæ of any species, one is enabled to determine the genus. For this scheme the order of development of the pleopods has been taken as the main factor, as it is found that the pleopods develop differently in several of the most important genera.

There are eleven genera of euphausiids recognised, i.e. Bentheuphausia, Pseudeuphausia, Euphausia, Thysanopoda, Nyctiphanes, Meganyctiphanes, Nematoscelis, Thysanoessa, Nematobrachion, Tessarabrachion, and Stylocheiron.

Nothing is so far known of the larval stages in Bentheuphausia, Nematobrachion, and Tessarabrachion, and of Pseudeuphaus a only enough to show that the young larva somewhat resembles that of Nyctiphanes. These four are, until more is known, left out of the following scheme. There remain seven genera, viz. Euphausia, Thysanopoda, Nyctiphanes, Meganyctiphanes, Nematoscelis, Thysanoessa, and Stylocheiron, the life histor es of which are more or less known and these form the basis of the present paper. 
Whilst working out the Channel species the complete series of larval stages was found and described (Lebour, 1924, 1925, 1926a) in Nyctiphanes Couchii, Meganyctiphanes norvegica, and Thysanoessa inermis. Miss Jorgensen (1925), from the North Sea material, has described several stages of Thysanoessa longicaudata and a few specimens of the same species were described from the Atlantic (Lebour 1926a), whilst Mr. R. Macdonald from Millport is preparing a description of the larval stages of Thysanoessa Raschii. From the Alexandria material an almost complete set of larval forms of Stylocheiron Suhmii was obtained and several stages of $S$. abbreviatum, a description of which is now published (Lebour, 1926b), and besides these there are in the Alexandria material almost complete series of the larval forms of Thysanopoda aqualis, Nematosce'is microps, and Euphausia Krohnii, with a few specimens of another larva, almost certainly an Euphausia. With these, together with the few published descriptions of larvæ by Sars, Hansen, Tattersall, and others, we can draw up a fairly comprehensive review of larval forms which considerably adds to our knowledge of the group.

The general order of development in the Euphausiidæ is the following : first the egg, which may be carried by the female (known in the genera Nyctiphanes, Stylocheiron, and Nematoscelis) or may be shed into the sea at an early stage of development (known in Meganyctiphanes and Thysanoessa). For several genera, however, the mode of egg deposition is not known, although it is probable that Euphausia and Thysanopoda shed them into the sea, and that Tessarabrachion and Nematobrachion carry them. In Nyctiphanes the eggs are carried until an advanced stage (Lebour, 1924), the nauplius only occurring inside the egg sac, and the young being shed into the water as a pseudometanauplius covered by a skin which is immediately sloughed on emergence and the metanauplius freed. Nauplii and metanauplii of Nematoscelis and Stylocheiron have not yet been seen. It is suggested by Calman (1909) that the young may emerge at an advanced stage in Stylocheiron, the eggs being so large. In the Alexandria material there are three Calyptopis stages, almost certainly belonging to Stylocheiron Suhmii. The smallest and youngest of these which is a first Calyptopis is quite small, measuring $1.28 \mathrm{~mm}$. in length, and might easily have come from one of the large eggs.

The typical procedure in an euphausiid is for a nauplius to hatch out of the egg into the water and this first nauplius almost immediately to slough its skin and become a second nauplius, this changing into a metanauplius. These are well described by Metschnikoff (1871) and Sars (1898). Typical forms are Meganyctiphanes norvegica and Thysanoessa inermis (Lebour, 1924, 1926a ; Brook and Hoyle, 1888; Elmhirst, 1924). No others are as yet completely known. In the Alexandria material metanauplii of Euphausia Krohnii were found. Thus the only euphausiid 
nauplii certainly known are those of Nyctiphanes Couchii (passed within the egg sac), Meganyctiphanes norvegica, and Thysanoessa inermis. Metanauplii have been described of Nyctiphanes australis (Sars, 1885), $N$. Couchii (Lebour, 1924), Meganyctiphanes norvegica (Sars, 1898; Lebour, 1924 ; Elmhirst, 1924), and Thysanoessa inermis (Lebour, 1926a). All of these are much alike, but differ in the armature of the carapace.

From the metanauplius comes the first Calyptopis, giving rise to the second and this to the third. All three stages are known in Nyctiphanes australis (Sars, 1885), N. Couchii (Lebour, 1924), Meganyctiphanes norvegica (Sars, 1898; Lebour, 1924; Elmhirst, 1924), Thysanoessa inermis (Lebour, 1924), Thysanoessa longicaudata (Jorgensen, 1925), Euphausia Krohnii (Sars, 1885, as E. pellucida, and also in the Alexandria material), the second and third Calyptopis of Thysanopoda tricuspidata, in which peculiar larval eyes are shown, are described by Sars (1885) and the three Calyptopis stages of what is almost certainly Stylocheiron Suhmii have been found in the Alexandria material. All the Calyptopis stages have the same general appearance with the eyes covered by the carapace, and the abdomen having no segments in the first, five in the second, and six in the last stage. There is no evidence to show that more than two naupliar and three Calyptopis stages exist in any species.

The last Calyptopis changes to the first Furcilia stage with the eyes uncovered by the carapace. In most of the species this has no pleopods, and it is probable that this stage without pleopods occurs in all. Such a Furcilia is known in Nyctiphanes Couchii, Meganyctiphanes norvegica, Thysanoessa inermis, T. longicaudata, Nematoscelis microps, Thysanopoda tricuspidata, and Stylocheiron Suhmii. In the following Furcilia stages the pleopods develop successively until all are setose and biramous, when they are capable of being used as swimming organs and the Furcilia then changes to a Cyrtopia, in which the antennæ are no longer used for swimming, the same being differentiated into scale and flagellum.

Generally speaking when once the Cyrtopia stage is reached it is fairly easy to place the specimen, at any rate in its genus, therefore a knowledge of the Furcilia stages is the more important for elucidating the life histories. It is proposed to deal more elaborately with those Furcilia stages in which the pleopods are developing, and on these base the scheme which will help to place the specimen in the genus to which it belongs.

It is found that the pleopods develop in different ways in several different genera of which the first three or four are the same and the last two or three are the same, but in between there are different orders of development, some of which appear to be characteristic of certain genera. If therefore a fairly complete series of larval stages is obtainable of any form we can place it within a group, and if this does not indicate 
the genus a few other known characters will probably identify it. Unfortunately a complete series of Furcilia stages is rarely obtainable, but enough has been elucidated within the last few years to bring a large amount of material together, and a survey of these brings much evidence to bear in favour of their grouping the genera for the purpose of larval identification. It is not suggested that this grouping should necessarily indicate natural phylogeny, for we find in some cases, e.g. Nyctiphanes and Nematoscelis, that genera develop alike which are usually placed in different families. At present the facts are indicated as a key to facilitate the identification of genera. The reason is probably to be found in the fact that more hurried growth is necessary for some than for others. Thus we find that one group develops the pleopods as slowly as possible so that all five are simple buds before any become setose, e.g. Thysanoessa. Here probably the swimming powers are delayed as none of the pleopods can as yet be used. Closely similar is Euphausia Krohnii, in which the first pleopod is setose, whilst four are simple, and then the group which is most commonly found, where the first is setose with three simple and the last is not yet formed. To this group belong the majority, including Nyctiphanes, Meganyctiphanes, Thysanopoda, Nematoscelis, and Euphausia, the last being slightly different, as, at any rate in the Krohnii group and possibly in all, there are, as shown above, four simple buds behind the first setose pleopod. In all the other genera cited the second pleopod becomes setose before the last bud appears. Finally, we have Stylocheiron in which the first pleopod is setose with only two simple buds behind. We have thus a gradual quickening of the development culminating in Stylocheiron.

The possible (or known) stages in development are given in the diagram and numbered 1 to 14 (Text Fig. 1). Each division represents an abdominal segment, the simple pleopods being indicated by one stroke, the setose pleopods by a fringed stroke. The figures do not necessarily refer to actual Furcilia stages. Thus 6 in the diagram is the sixth Furcilia of Thysanoessa, but 7 in the diagram is the fourth Furcilia of Stylocheiron and 8 in the diagram is the sixth Furcilia of Nyctiphanes.

The following list enumerates all known larval stages, numbered according to the diagram, in all the species where they are known, as far as the Furcilia numbered 14. There may, however, be several Furcilia stages with all the pleopods setose. In this list there are many gaps, but it will be seen that closely related genera and species belonging to the various genera agree as to the development, and that so far no larval stages are known which disagree. 
Fig. 1.

Diagram to Illustrate the Development of Pleopods in Euphausim Furcilia Stages.

\section{$1 \square \square \square \square \square$ No pleopods}

Probably common to all.

$2 \square \square \square \square \square$ one pair simple pleopods.

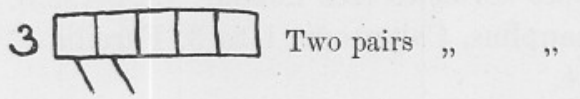

Probably common to all except Stylocheiron.

4

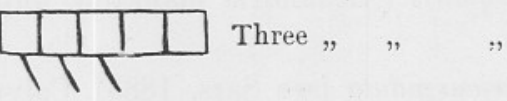

5

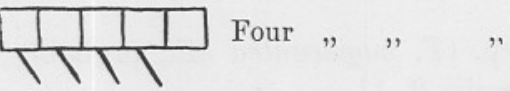

6

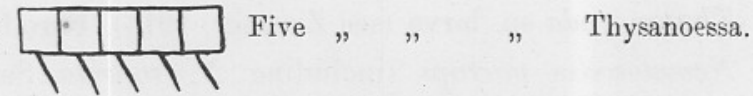

7 \begin{tabular}{|l|l|l|l}
\hline & 1 & 1 & One pair setose, two pairs simple- \\
Stylocheiron.
\end{tabular}

8 $\lambda 1$

One pair setose, three pairs simpleNyctiphanes, Meganyctiphanes, Thysanopoda, Euphausia, Nematoscelis.

9

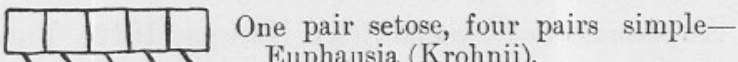
111 Euphausia (Krohnii).

10

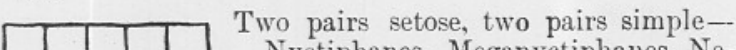
Nyctiphanes, Meganyctiphanes. Nematoscelis, Thysanopoda.
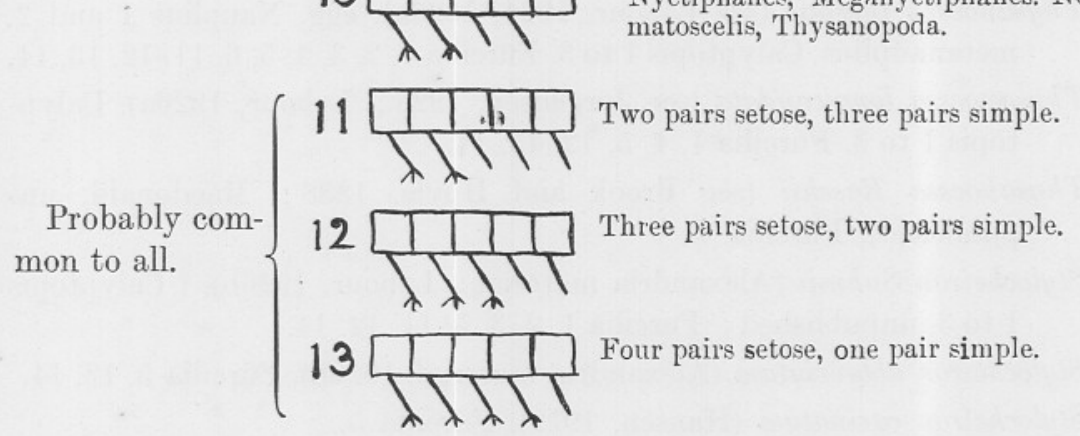

Commonto all. $14 \square$ all setose. 


\section{Early Larval and Furcilia Stages known in the VARIOUS SPECIES.}

Nyctiphanes Couchii (see Lebour, 1924, 1925), egg, nauplius, pseudometanauplius, metanauplius, Calyptopis 1 to 3 , Furcilia $1,2,3,4,5$, $8,10,11,12,13,14$.

Nyctiphanes australis (see Sars, 1885), metanauplius, Calyptopis 1 to 3.

Nyctiphanes simplex (Hansen, 1912), Furcilia 11.

Meganyctiphanes norvegica (see Lebour, 1924-1925), egg, Nauplius 1 and 2, metanauplius, Calyptopis 1 to 3 , Furcilia 1, 2, 3, 4, 5, 8, 10, 11, $12,13,14$.

Thysanopoda aqualis (Alexandria plankton, unpublished), Furcilia 1, 3, $10,13,14$.

Thysanopoda tricuspidata (see Sars, 1885), Calyptopis 2 and 3, Furcilia 1,4 .

Thysanopoda sp. (T. monacantha aff., probably $T$. cristata, see Hansen, 1912), Furcilia 2, 11.

Thysanopoda sp. larva (see Zimmer, 1914), Furcilia 14 or later.

Nematoscelis microps (including $N$. rostrata Sars, 1885; Alexandria plankton, unpublished; Hansen, 1912), Furcilia 2, 8, 13, 14.

Euphausia Krohnii (see Sars, 1885, as E. pellucida; Alexandria plankton unpublished), metanauplius, Calyptopis 1 to 3 , Furcilia 2, 9, 14.

Euphausia longirostris (see Tattersall, 1924; Sars, 1885), Furcilia 2, 8, $13,14$.

Euphausia spinifera (see Tattersall, 1924), Furcilia 2. (?)

Euphausia distinguenda (see Hansen, 1912), Furcilia 13.

E. sp. (Alexandria Plankton, unpublished) Calyptopis 1 and 2, Furcilia 1, 2,8 .

Thysanoessa inermis (see Lebour, 1924, 1926a), egg, Nauplius 1 and 2, metanauplius, Calyptopis 1 to 3, Furcilia 1, 2, 3, 4, 5, 6, 11, 12, 13, 14 .

Thysanoessa longicaudata (see Jorgensen, 1925 ; Lebour, 1926a), Calyptopis 1 to 3 , Furcilia $1,4,5,12,13,14$.

Thysanoessa Raschii (see Brook and Hoyle, 1888; Macdonald, unpublished), Furcilia 6 .

Stylocheiron Suhmii (Alexandria material ; Lebour, 1926b), ? Calyptopis 1 to 3 , unpublished ; Furcilia 1, 2, 3, 5, 11, 12, 14.

Stylocheiron abbreviatum (Alexandria material, 1926b), Furcilia 5, 12, 14. Stylocheiron carinatum (Hansen, 1912), Furcilia 5. 
The larvæ described by Colosi (1922) as Nematoscelis microps seem to belong either to Nyctiphanes or Meganyctiphanes.

It is thus seen that the evidence is in favour of a certain order of development of the pleopods in the various genera, and so far there is none against this. So that on finding a larva with one pair of pleopods setose and two pairs simple one would immediately place it in the genus Stylocheiron, and on finding one with five pairs of simple pleopods it would be placed in the genus Thysanoessa. Fortunately these distinctive stages nearly always seem to occur as though certain stages were dominant. Such dominant stages are Furcilia 5 (presumably the fourth Furcilia stage) in Stylocheiron, and Furcilia 6 (presumably the sixth Furcilia stage) of Thysanoessa; also Furcilia 9 (presumably the seventh Furcilia stage) of Euphausia Krohnii.

In the Nyctiphanes group of this scheme, which includes Nyctiphanes, Meganyctiphanes, Thysanopoda, and Nematoscelis, the first two, with the Thysanopoda sp. of Zimmer (1914), are recognisable by their truncated rostra. Other Thysanopoda and Nematoscelis may be very much alike, but distinguishable in many of the Furcilia stages by the growth of the second thoracic limb, which is very long in Nematoscelis. Euphausia apparently has Furcilia 8 in common with the Nyctiphanes group, but differs in E. Krohnii (and possibly in other species) by going through the Furcilia 9 stage, which does not occur in the Nyctiphanes group.

There is distinct evidence of the jumping of stages in some species. If kept in aquaria both Nyctiphanes and Meganyctiphanes may jump stages. Mr. Elmhirst and Mr. Macdonald from Millport tell me that Meganyctiphanes may jump several stages, but they always jump into a stage known for that genus. Thus Nyctiphanes might jump from a stage with three simple pleopods to one with two setose and two simple, but it would not jump to five simple pleopods, which is characteristic of Thysanoessa, neither would it jump to one pair setose and four simple, which is characteristic of Euphausia Krohnii. Mr. Elmhirst has kindly provided me with some notes on Meganyctiphanes (reared in aquaria) in which one jumped from one to three pairs of simple pleopods and one which jumped from three pairs of simple pleopods to three pairs setose and two pairs simple, that is from Furcilia 4 to 9 , thus missing out eight altogether. Thus we may expect the development of any species to proceed in a particular way even though stages may be jumped, and it is quite possible that in some of those given in the lists the jumping of stages is the usual thing.

Taking all these facts into consideration we may now suggest a key for the elucidation of larval euphausiids, so as to place them in their respective genera. Only eight genera are taken, as no larval forms of the other three are known. Pseudeuphausia is included, as it can be 
recognised in the larval stage by its rostrum (Hansen, 1912), but the development of its pleopods is unknown.

The genera may be grouped thus :-

Group I. Second pleopod becomes setose before the appearance of the fifth-Nyctiphanes, Meganyctiphanes, Thysanopoda, Nematoscelis.

Group II. A stage present with all five pleopods simple-Thysanoessa.

Group III. A stage present with first pleopod setose and four simple-. Euphausia (Krohnii) (the stage preceding this having one pair setose and three simple).

Group $I V$. A stage present with the first pleopod setose and two simple Stylocheiron.

Key.

I. Rostrum truncated.

1. Rostrum deeply emarginate anteriorly-Pseudeuphausia.

2. Rostrum almost straight anteriorly.

(a) Abdominal segments without lateral processes.

a. Carapace very broad-Meganyctiphanes.

B. Carapace not very broad-Nyctiphanes.

(b) Abdominal segments with lateral processes-Thysanopoda (in part. See T. sp. Zimmer, 1914).

II. Rostrum pointed or rounded.

1. First pleopod becomes setose before the fourth appears-Stylocheiron.

2. Fourth pleopod appears before any are setose.

(a) Fifth pleopod appears before any are setose-Thysanoessa.

(b) First pleopod becomes setose before the fifth appears.

a. Fifth pleopod appears before the second is setose-Euphausia (E. Krohnii).

B. Second pleopod becomes setose before the fifth appears.

(i) Second thoracic leg becomes long at an early stage-Nematoscelis.

(ii) All thoracic legs short-Thysanopoda (in part, e.g. T. aqualis).

\section{LITERATURE.}

1888. Вrook, G., and Hoyle, W. E. The Metamorphosis of British Euphausiidæ. Proc. Roy. Soc., Edinburgh, July 2, 1888.

1909. Calman, W. T. "Crustacea" in "A Treatise on Zoology," edited by Sir Ray Lankester, Pt. VII.

1922. Colosi, G. Eufausiacei e Mysidacei raccolte nella Campagne del 1920. R. Com. Tal. It. Mem. XCII.

1924. Elmhirst, R. Annual Report, Scottish Marine Biological Association for 1922 . 
1912. Hansen, H. J. The Schizopoda. Rep. Sci. Results of the Exp. in the E. Tropical Pacific, etc., by the U.S. Fish Comm. steamer Albatross. Comp. Zool. Harvard, Vol. XXXV, No. 4.

1925. Jorgensen, O. Some Crustacean Larvæ from the Northumberland Plankton. Trans. Nat. Hist. Soc. of Northbd., Durham and Newcastle-upon-Tyne, N.S., Vol. VI, Pt. II.

1924. Lebour, M. V. The Euphausiidæ in the Neighbourhood of Plymouth and their Importance as Herring Food. Jour. Mar. Biol. Assoc., Vol. XIII, No. 2.

1925. Lebour, M. V. The Euphausiidæ in the Neighbourhood of Plymouth, II. Nyctiphanes Couchii and Meganyctiphanes norvegica. Ibid., Vol. XIII, No. 4.

1926a. Lebour, M. V. The Euphausiidæ in the Neighbourhood of Plymouth, III. Thysanoessa inermis. Ibid., Vol. XIV, No. 1.

1926b. Lebour, M. V. The Young of Stylocheiron Suhmii, G. O. Sars, and Stylocheiron abbreviatum, G. O. Sars (Crustacea), from Mediterranean Plankton collected by Mr. F. S. Russell in the neighbourhod of Alexandria, Egypt. Proc. Zool. Soc., London, Part I.

1871. Metschnikoff, E. Ueber den Naupliuszustand von Euphausia. Zeit. f. Wies. Zool., XXI, 4.

1885. Sars, G. O. Report on the Schizopoda collected by H.M.S. Challenger, etc.

1898. Sars, G. O. On the Propagation and Early Development of Euphausiidæ. Archiv. Math. Naturvid., 20.

1924. Tattersall, W. M. Euphausiacea in Brit. Antarctic "Terra Nova " Exp., 1910. Crustacea, Part VIII.

1914. Zimmer, C. Die Schizopoden der Deutscher Südpolar-Expedition, 1901-1903. 
